Contents List available at RAZI Publishing

Pakistan Journal of Geology (PJG)

Journal Homepage: http://www.razipublishing.com/journals/pakistan-

journal-of-geology-pjg/

\title{
Microfacies and Diagenetic Analysis of Lockhart Limestone, Shah Alla Ditta Area Islamabad, Pakistan
}

\section{Zeeshan Khattak ${ }^{1}$, Mumtaz Ali Khan ${ }^{1}$, Zain ur Rahman ${ }^{1}$, Muhammad Ishfaque ${ }^{2}$, Muhammad Yasin ${ }^{2}$}

${ }_{2}^{1}$ Department of Earth \& Environmental Sciences, Bahria University Islamabad, Pakistan.

2 Insitute of Geology, The university of Azad Jammu and Kashmir, Muzaffarabad, Pakistan.

This is an open access article distributed under the Creative Commons Attribution License, which permits unrestricted use, distribution, and reproduction in any medium, provided the original work is properly cited

\section{ARTICLE DETAILS}

Article history:

Received 24 October 2016 Accepted 7 December 2016 Available online 3 January 2017

Keywords:

Microfacies and Diagenetic Analysis of Lockhart Limestone.

\section{ABSTRACT}

The Larger Foraminifera made a major contribution to Paleocene and Eocene biota. The microfacies and diagenetic setting of the Paleocene Lockhart Formation were analyzed in Shah Alla Ditta area, Islamabad. The Lockhart Formation is highly fossiliferous, comprising of thin nodular limestone with interbedded shale/ marl. The lower contact is unconformable with Jurassic Samansuk formation while the upper contact is conformable with Margalla Hill Limestone. Rock samples were collected from the field and thin sections were prepared and analyzed under the microscope and on the basis of detailed petrographic study three types of microfacies were identified and interpreted based on Dunham's textural classification, allochem type, fossil content and sedimentary structures. The microfacies include: LH-MF 1: Foraminiferal Wackestone/ Biomicrite Microfacies, LH-MF 2: Algal Foraminiferal Wackestone Microfacies, LH-MF 3: Mixed Bioclastic Mudstone Microfacies. A number of larger benthic foraminifera, and the lack of Planktonic foraminifera in the Lockhart Limestone, indicate shallow to deep water of restricted inner to middle shelf environment of deposition. Larger foraminifera and dasycladacena algae are the two major fossil contents present in the Lockhart Formation. Larger foraminiferal species like Lockhartia hameii and Lockhartia conditi present in the formation confirm the age of Lockhart Limestone as Paleocene. The main diagenetic fabric recognized in the limestone reveals mechanical and chemical compaction, deep burial water pressure, pressure solution and tectonics-related fracturing. The nodularity in the limestone is credited to pressure solution.

\section{Introduction}

The Shah Alla Ditta area is located in the foothills of the Margalla hill ranges which are part of the NW Himalayan foreland fold and thrust belts of Pakistan and are related to the main zone of Himalayan convergence (Jadoon, 1992). A major thrust fault, the Panjal-Khairabad fault, divides the NW Himalayan sequence into a deformed southern zone often referred to as the external or Foreland zone, and a deformed and metamorphosed zone also known as the Hinterland zone (DiPietro et al., 1996; Pivinik et al., 1996) (Figure. 1). The Paleocene stratigraphic succession is well exposed throughout the area.

The emphasis of the present study is on microfacies analysis and the diagenetic history of the Lockhart limestone. Dunham (1962) scheme is used to classify the rocks and Flügel (2004) is used for the identification of microfacies and interpretations. The standard microfacies scheme of Wilson (1975) is also used for the comparison of identified microfacies.

\section{Geological Setting}

Geologically the study area is situated in the fault zone of the Main Boundary Thrust (MBT) and the Punjal thrust (PT), (Figure. 2). The overall structural grain of the area is NE-SW. The Main Boundary Thrust (MBT) is well exposed in this area and is located in the southern part of the study area, in Islamabad. It carries Jurassic Samansuk Formation over Miocene Muree Formation at the surface. The strike of the fault is ENE to WSW. The average dip of the fault is 35 degrees to 40 degrees towards the north. The lithologies present in the area have a strong influence on the style of faulting. In the study area the exposed stratigraphy ranges from the Mesozoic to the Cenozoic era. The oldest formation is the Samanasuk Formation of Jurassic age. The Lockhart and Patala Formations are of Paleocene age. The Margalla Hill limestone is of Eocene age, and the Murree Formation of Miocene age is present in the area. The Lockhart Limestone has an unconformable contact with the underlying Jurassic Samanasuk while its upper contact is conformable with the Eocene Margalla Hill Limestone. The youngest formation exposed in the area is the Muree Formation (Figure. 3).

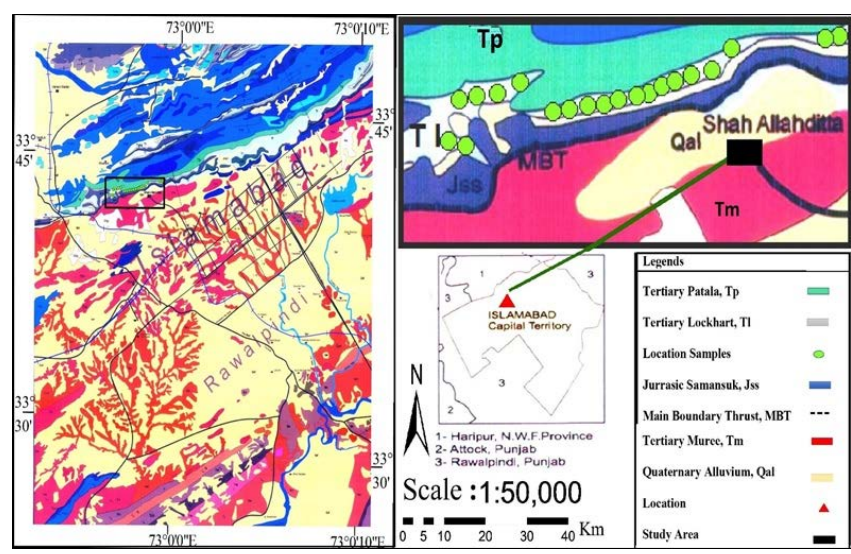

Figure 01 Accessibility map of study area, black box shows the study area.

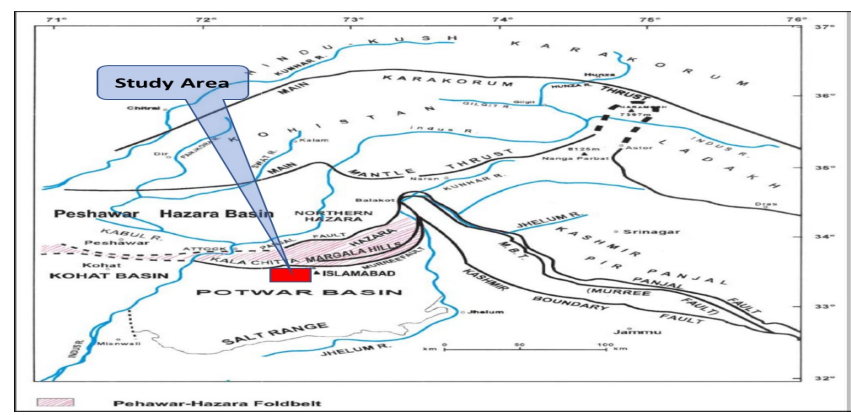


Figure. 2 Geological map of northern Pakistan showing major structure boundaries, the study area is indicated by diagonal ruling. (modified after Ghazanfar et al., 1990).

\begin{tabular}{|c|c|c|c|c|c|}
\hline Era & Epoch & Period & Formation & Lithology & Symbols \\
\hline \multirow{3}{*}{ 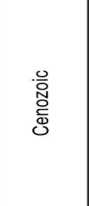 } & \multirow{3}{*}{ 產 } & 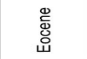 & $\begin{array}{l}\text { Margalla } \\
\text { Formation }\end{array}$ & $\begin{array}{l}\text { Limestone,Marı } \\
\text { and Shale }\end{array}$ & 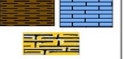 \\
\hline & & 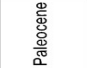 & $\begin{array}{l}\text { Patala } \\
\text { Formation }\end{array}$ & Shale and Limestone & 空 \\
\hline & & 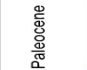 & $\begin{array}{l}\text { Lockhart } \\
\text { Formation }\end{array}$ & Limestone and Shale & \\
\hline Mesozoic & \multicolumn{2}{|c|}{ Jurassic } & $\begin{array}{l}\text { WWWWW } \\
\text { Samanasuk } \\
\text { Formation }\end{array}$ & $\begin{array}{l}\text { WMWWWWMYMWW } \\
\text { KLimestone,Sandston }\end{array}$ & WW \\
\hline Cenozoic & Tertiary & Miocene & $\begin{array}{l}\text { Muree } \\
\text { Formation }\end{array}$ & Sandstone and clay & \\
\hline \multicolumn{6}{|l|}{ Legends } \\
\hline 窴空 & \multicolumn{2}{|l|}{ Limestone } & & بـــــ & Thrust Fault \\
\hline & \multicolumn{2}{|l|}{ Clay / Shale } & 管高 & WWun & Unconfirmity \\
\hline
\end{tabular}

Figure. 3 A brief description of the stratigraphy involved in the Shah Alla Ditta area.

\section{Methodology and Data}

Twenty samples were collected from the Shah Alla Ditta area. Detailed measured sections in the field were used to describe the facies and to determine sample locations (Figure. 5). Thin sections of all samples were prepared. The Dunham (1962) and Embry and Klovan (1971) classifications were used for the microfacies identification and interpretation.

\section{Results}

\subsection{Microfacies Analysis}

On the basis of detailed petrographic and micropalaeontological studies three types of microfacies were recognized with distinct texture, allochem types, fossil contents and sedimentary structures. The Lockhart limestone microfacies are, from the base of the formation upwards:

\subsection{Lockhart-Microfacies 1: Foraminiferal Wackestone/Biomicrite} Microfacies.

This microfacies is mainly characterized by skeletal allochems which are the only allochemical constituents marked by moderate diversity of organisms. These skeletal allochems include: larger benthic foraminifers, gastropods, pelecypods, ostracods and rare dasycladacean algae. The benthic foraminifers constituting $20-45 \%$ of the skeletal constituents include, Miscellinae miscella, Lockhartia hameii, Lockhartia conditti, Ranikotalia trochodiformis, Quenquloclina sp., Idalina sinjarica sp., and Cibicide (Figure 4a). "Dunham(1962) recognizes wackestone as a textural type in this microfacies, while Folk calls the same material 'poorlywashed biomicrite.(1959)"

4.3 Lockhart-Microfacies 2: Algal Foraminiferal Wackestone Microfacies. The Algal-Foram Wackestone Microfacies is comprised of dark grey, thin bedded, nodular limestone with minor clay/marl interbeds. It is characterized by larger and smaller benthic foraminifera mixed with dasycladacean algae, mollusks, gastropods and ostracods with rare echinoderms and planktic foraminifera. The dasycladacean algae vary from $10-15 \%$. The benthic foraminifera constitute $20-25 \%$ of the skeletal constituents and include milliolids, Lockhartia sp., Rotalia sp., Textularia and Assilina sp. (Figure. 4b)

4.4 Lockhart-Microfacies 3: Mixed Bioclastic Mudstone Microfacies The allochem constituents are exclusively skeletal fragments displaying mudstone depositional fabrics according to Dunham (1962), or poorly washed biomicrite according to Folk (1959). Algae, Miscellanea miscella, and a very few smaller benthics are also observed in these sections. Mostly the calcite veins found in this mocrofacies replace bioclasts. The veins are parallel to subparallel, and also cross-cut each other. This type of cross cutting is evidence of a tectonically highly fractured zone. (Figure. 4c).
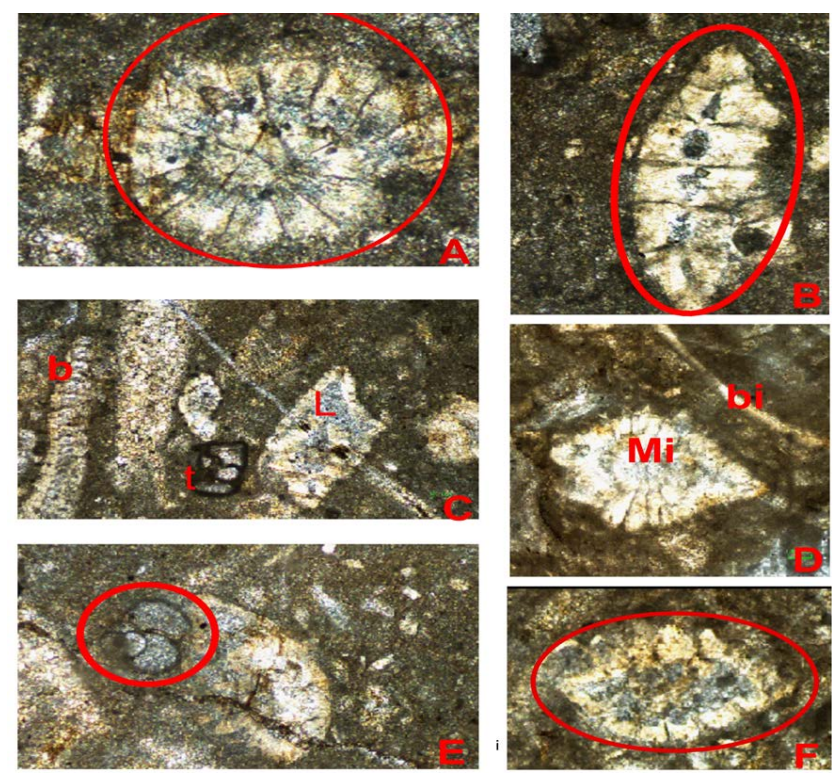

Figure. 4a. Photomicrograph displaying Assilina (A), Rotalia Trichodoformis (B), (b) Bioclast (t) Textularia and (L) Lockhartia sp. (C), Rotalia sp. (D), (Mi) Miscellanea sp. and (bi) Bivalve (D), Planorotalite pseudominaradi (E), Lockhartia haimei (F) in lime mud matrix in Foraminiferal Wackestone Microfacies.
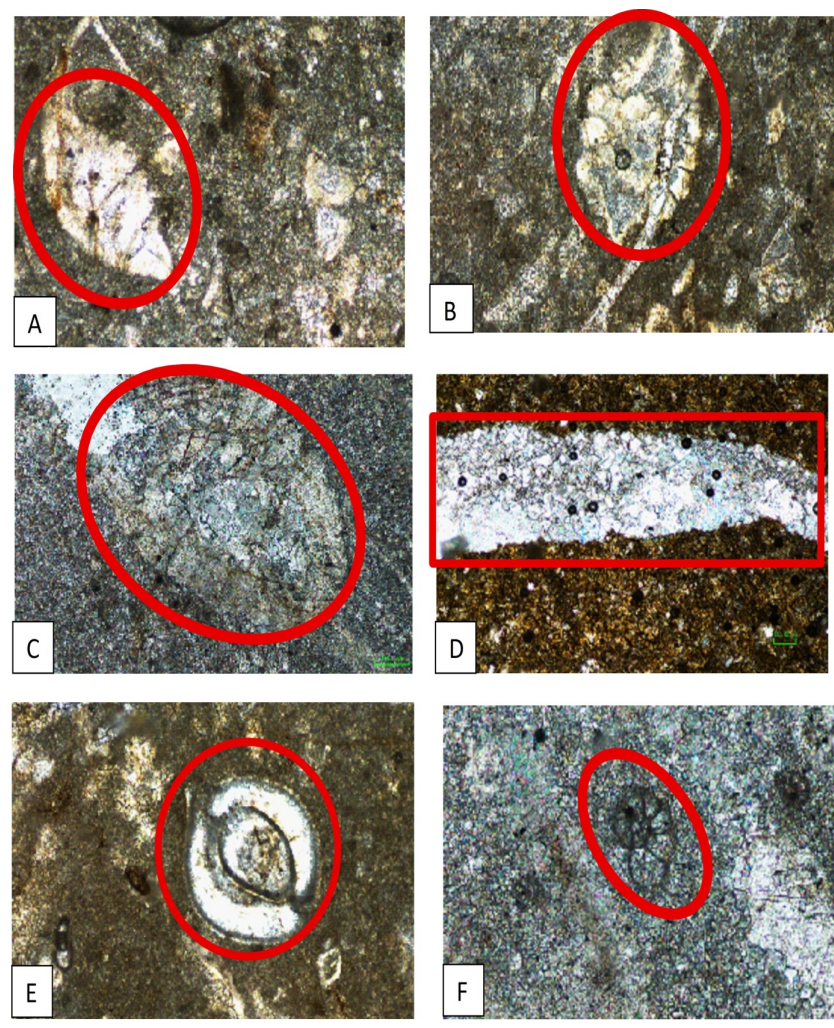

Figure. 4b. Photomicrograph displaying Lockhartia sp (A, B), Fossil replacement by calcite (C),Calcite vein (D), Quinqueloculina (E), Assilina (F) in Algal Foraminiferal Wackstone.

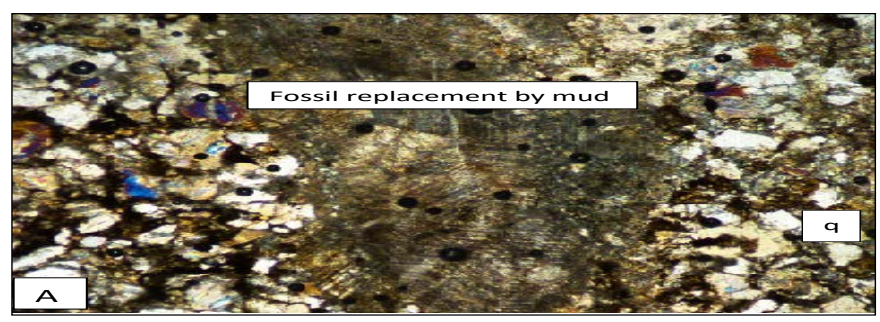



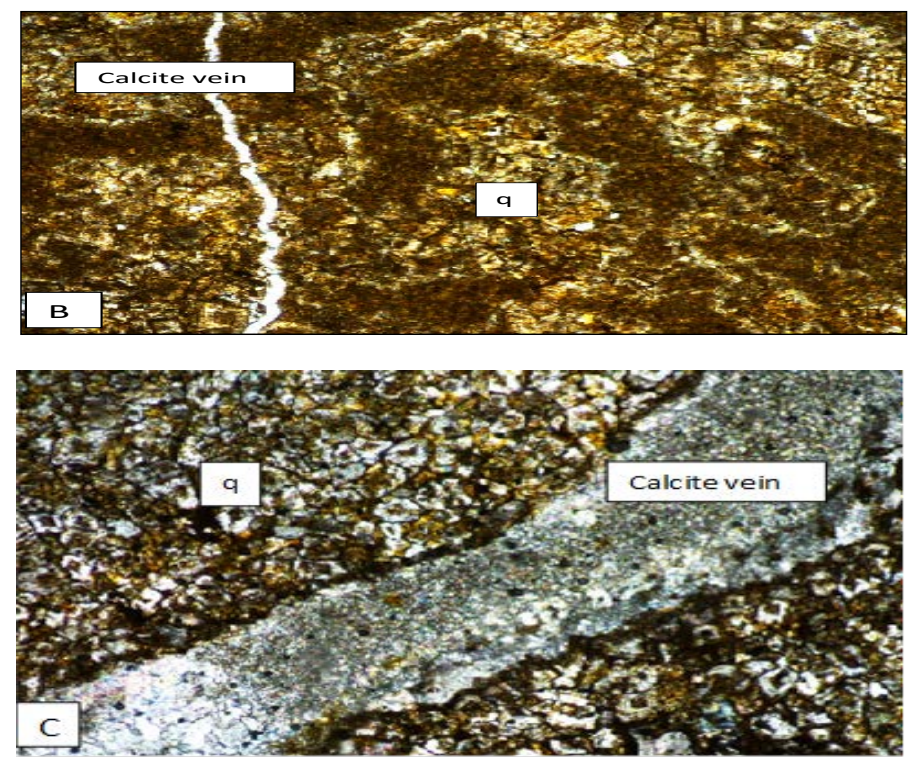

Figure. 4c. Photomicrograph displaying (A) fossil replacement by mud and (B) \&(C) calcite vein and (q) quartz crystal in mixed bioclast mud stone facies.

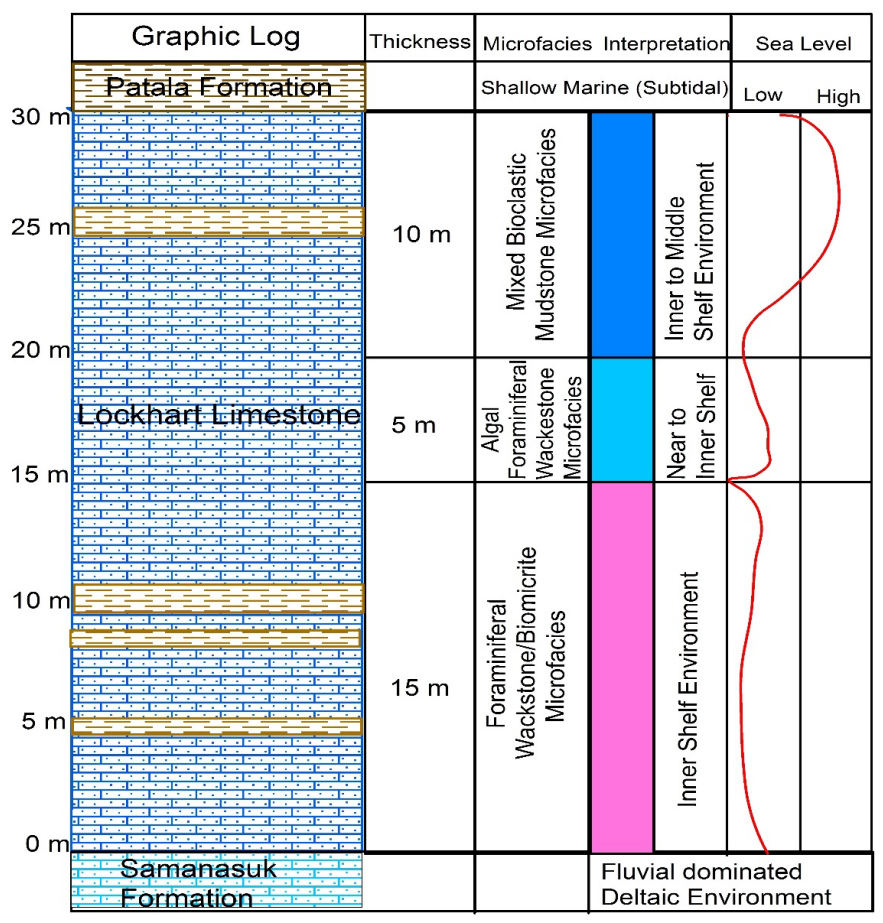

Figure. 5. Showing the depositional environment of microfacies with respect to sea level rise and fall.

\section{5. . Discussion}

The microfacies identification and interpretation shows that the Lockhart Limestone represents deposition in near-shore, inner to middle shelf environments, (Figure. 5). The sea level changes control the distribution of microfacies, which reveal the onset of shallow marine conditions. During sea level still-stand the Foraminiferal Wackestone/Biomicrite Microfacies was deposited. Times of gradual sea level rise are associated with the deposition of Mixed Bioclastic Mudstone Microfacies. The Algal Foram Wackestone in the middle of the Lockhart Limestone indicates sea level fall and inner shelf subtidal settings.

\subsection{Diagenesis}

The diagenesis encompasses all the processes affecting carbonate rocks until the realm of incipient metamorphism at elevated temperature and pressure (Tucker and Wright, 1990). The diagenetic processes characteristic of the Lockhart Limestone are responsible for the development of typical features diagnostic of those regimes. These processes include compaction, transformation of aragonite to more stable low-Mg sparry calcite, and pressure solution.

\section{Conclusions}

Three microfacies are recognized in outcrops of Shah Alla Ditta area:

$>\quad$ Foraminiferal Wackestone/Biomicrite Microfacies,

deposited during sea level still stand.

$>\quad$ Algal Foraminiferal Wackestone Microfacies, laid down during sea level fall.

$>\quad$ Mixed Bioclastic Mudstone Microfacies representing sea level rise.

These three microfacies represent inner shelf, near shore to innershelf and inner to middle shelf environments of deposition.

\section{Acknowledgement}

I am special thankful to my all friends and family member who support me during my research work. After this, Iam immensely grateful to faculty and Department of Earth \&amp; Environmental Sciences, Bahria University Islamabad,Pakistan.

\section{Funding Information}

The funding for this research is provided by the Department of Earth \& Environmental Sciences, Bahria University Islamabad, Pakistan

\section{Author's Contributions}

Zeeshan Khattak

Data Collection, Data Analysis, Data interpretation, Result finalization.

\section{Mumtaz Ali Khan}

Literature Review

\section{Zain ur Rahman}

Sampling during field work

\section{Muhammad Ishfaque, Muhammad Yasin}

Result Interpretation and paper writing

\section{Ethics}

This article is original and contains unpublished material. The corresponding author confirms that all of the other authors have read and approved the manuscript and no ethical issues involved in this manuscript.

\section{References}

[1] Dunham, R.J., 1962. Classification of carbonate rocks according to depositional texture. In: Classification of Carbonate Rocks. W. E. Ham, edition, Memoirs, American Asociation of Petroleum Geologists, 1: 108-121.

[2] Embry, A.F., Klovan, J.E., 1971, A Late Devonian reef tract on northeastern Banks Island, NWT: Canadian Petroleum Geology Bulletin, 19: 730-781.

[3] Flügel, E., 2004. Microfacies of carbonate rocks, analysis, interpretation and application. Springer-Berlin, Heidelberg, New York.

[4] Folk, R.L, 1959. Practical petrographic classification of limestone. Bulletin American Association of Petroleum Geology, 43: $1-38$.

[5] Jadoon, I.A.K., 1992. Thin-skinned tectonics on continent/ ocean transitional crust, Sulaiman Range, Pakistan. Unpublished Ph.D. thesis. Geology Department Oregon State University USA.pp. 23-30.

[6] Tucker, M.E and Wright, V.P. 1990. Carbonate sedimentology, Blackwell Scientific Publications Oxford London, 23-25.

[7] Wilson, J.L., 1975. Carbonate Facies in Geologic History, Springer-Verlag, Berlin, $471 \mathrm{p}$. 